\begin{tabular}{|c|c|c|}
\hline & International Journal of Current Research in \\
Biosciences and Plant Biology & Volume 5 • Number 8 (August-2018) ・ ISSN: 2349-8080 (Online) \\
\hline EXCELLENT \\
PUBLISHERS
\end{tabular}

\title{
Phytoplasma Detection on Sugarcane Crops in South Sulawesi
}

\section{Catur Yogo Hendro Utomo ${ }^{1 *}$, Baharuddin ${ }^{2}$ and Nur Amin ${ }^{2}$}

\author{
1Master Program, Department of Plant Pests and Diseases, Hasanuddin University, Makassar, \\ South Sulawesi, 90245, Indonesia \\ 2Departement of Plant Pests and Diseases, Faculty of Agriculture, Hasanuddin University, Makassar, \\ South Sulawesi, 90245, Indonesia
}

${ }^{*}$ Corresponding author.

\begin{tabular}{ll}
\hline A rticle Info & A B S TRA C T \\
\hline $\begin{array}{l}\text { Date of Acceptance: } \\
\text { 23 July } 2018\end{array}$ & $\begin{array}{l}\text { Sugarcane yellow leaf syndrome has been found in South Sulawesi. The aim of this } \\
\text { study was to detect phytoplasmas associated with the symptomatic and asymptomatic } \\
\text { sugarcane. This study included sampling both symptomatic and asymptomatic leaves, } \\
\text { 06 August 2018 }\end{array}$ \\
$\begin{array}{l}\text { DNA extraction, detection phytoplasma using nested PCR, sequencing and } \\
\text { Confirmation using Basic Local Alighment Search Tool (BLAST) program. Detection using } \\
\text { Keyw ords }\end{array}$ & $\begin{array}{l}\text { nested PCR shows the amplification of the 1250 bp DNA band showing the presence of } \\
\text { phytoplasma both symptomatic and asymptomatic leaves. This means that sugarcane } \\
\text { crop in South Sulawesi has been infected with phytoplasmas. }\end{array}$ \\
\hline $\begin{array}{l}\text { Phytoplasma } \\
\text { Yellow leaf syndrome }\end{array}$ & \\
\hline
\end{tabular}

\section{Introduction}

South Sulawesi province has a total area of planting sugarcane about 10,588 ha with production 26,633 tons (Directorate General of Plantation, 2015). In order to achieve self-sufficiency target, it is necessary to increase the area of planting to 6,000 to 7,000 ha of smallholder plantations. Currently, the plantation area is only 3,800 ha (Government of South Sulawesi Province, 2017). As with other crops, sugarcane crops are also experiencing pest and disease problems. One of the pathogens in sugarcane plants is phytoplasma. Some diseases of sugarcane are sugarcane grassy shoot (SCGS), sugarcane white leaf (SCWL), sugarcane green grassy shoot (SCGGS), sugarcane leaf yellows and Ramu stunt (Rao and Marcone, 2012).

Sugarcane grassy shoot disease (SCGS) is reported to occur in India, Bangladesh, Malaysia, Nepal, Pakistan, Sri Lanka, Sudan and Thailand. In Thailand the disease is known as rokkortakri. In India, the disease is found in Uttar Pradesh with an incidence of disease ranging from 3 to $56 \%$ and a decrease in yields can reach $60 \%$ (Tiwari et al., 2012). Sugarcane white leaf disease (SCWL) is one 
of the main problems in cultivation of sugarcane in Thailand. In Thailand the disease is known as rokbaikhao (CABI, 2007). It was reported in 2010 that the disease caused losses in the sugarcane industry in Thailand to 30 million US dollars each year (Wongkaew, 2012). Sugarcane green grassy shoot (SCGGS) disease was first discovered in Thailand. In 2006 the disease was first found in Vietnam and caused an epidemic mainly in Nghe An province and caused a decrease in production at the NAT \& L Quy Hop Sugar factory from $1.2 \mathrm{~m}$ tones in 2007 to 2008 to $0.6 \mathrm{~m}$ tones in $2008-2009$ (Sugar Research Australia, 2013). Detection and identification of the presence of pathogens in plants is a first step in determining the next steps including control efforts. The existence of phytoplasma in sugarcane in South Sulawesi has never been done. This needs to be done in anticipation of the possibility of phytoplasma in sugarcane crops that can cause losses in the future. Phytoplasma in sugar cane is able to disrupt the process of chlorophyll synthesis that can cause a decrease in the amount of chlorophyll more than 90\% (CABI, 2007). The purpose of this study was to determine the presence of phytoplasma in sugarcane in South Sulawesi.

\section{Materials and methods}

\section{Sampling}

Leaf samples showed symptoms of yellowing leaves taken in Bone, Gowa and Takalar districts. The leaf samples taken were symptomatic and asymptomatic leaves. Sampling is done by purposive sampling. As a comparison used infected sample of infected phytoplasma grass (data not shown).

\section{DNA extraction}

Total DNA extraction based on existing protocols in the Dneasy Plant Mini Kit (Qiagen).

\section{PCR amplification}

Amplification of DNA extracted in running using two pairs of primers P1 (5'-AAG AGT TTG ATG CTG GCT CAG GAT T-3 ') (Deng and Hiruki 1991)/ P7 (5'-CGT CCT TCA TCG GCT CTT-3') and continued with the primary pair $\mathrm{R} 16 \mathrm{~F} 2 \mathrm{n}\left(5^{\prime}-\right.$ GAA ACG ACT GCT AAG ACT GG-3 ') / R16R2 (5'-TGA CGG GCG GTG TGT ACA AAC CCC G-3') (Gundersen and Lee, 1996).

The PCR reaction was performed at a $25 \mathrm{ml}$ volume consisting of $2 \mathrm{ml}$ of DNA template, $1 \mathrm{ml}$ of forward primer, $1 \mathrm{ml}$ of reverse primer, $21 \mathrm{ml}$ of nuclease free water and PuReTaq ${ }^{\mathrm{TM}}$ Ready-To$\mathrm{Go}^{\mathrm{TM}}$ PCR beads (GE Healthcare). PCR process using $\mathrm{P} 1 / \mathrm{P} 7$ primer pair denaturation at $94{ }^{\circ} \mathrm{C}$ for 30 seconds (4 minutes in first cycle), annealing at $55{ }^{\circ} \mathrm{C}$ for 1.5 minutes, and extention at $72{ }^{\circ} \mathrm{C}$ for 1.5 minutes (10 minutes in the last cycle). Performed 30 cycles. The $2 \mu \mathrm{l}$ of the first PCR result used as template for the second PCR process using R16F2n /R16R2 primer pair was denaturation at $94{ }^{\circ} \mathrm{C}$ for 30 seconds ( 4 minutes in first cycle), annealing at $56{ }^{\circ} \mathrm{C}$ for 1.5 minutes and extension at temperature $72{ }^{\circ} \mathrm{C}$ for 1.5 minutes $(10$ minutes in last cycle). Performed 30 cycles.

\section{Electrophoresis and visualization of DNA}

DNA visualization was performed with a $1.5 \%$ agarose gel in TAE $1 \times$ buffer $(0.04 \mathrm{M}$ Tris acetate, $0.01 \mathrm{M}$ EDTA). The agarose gel mixture was heated in a microwave until completely dissolved and $2 \mu$ ethidium bromide was added. After hardening, the agarose gel is transferred into the electrophoresis tub until submerged. A total of 3 - 5 $\mu l$ amplified DNA plus $2 \mu$ l loading buffers were included in the gel wells and electrophoresed at 100 volts for 30 minutes and the DNA bands visualized using a UV transilluminator.

\section{DNA sequencing}

Sequencing of phytoplasma DNA were done using primer pair R16F2n / R16R2. The sequence of DNA was confirmed using Basic Local Alignment Search Tool (BLAST) program at The National Center for Biotechnology Information (NCBI). 


\section{Results and discussion}

\section{Symptoms of sugarcane associated with phytoplasma}

Sugarcane crops associated with phytoplasma show symptoms of yellowing midrib (Fig. 1a) when compared with asymptomatic plants (Fig. 1b). Symptomatic sugar cane plants also look shorter. Sugarcane plants that show symptoms of yellowing midrib leaves are called yellow sugarcane leaf syndrome (YLS) (Arocha et al., 2005). These symptoms have also been found in Cuba (Arocha et al., 2005), India (Gaur and Rao 2008) and Egypt (ElSayed and Boulila, 2013). In Cuba the disease is transmitted by the vector Saccharosydney saccharivora (Arocha et al., 2005). In India, of all symptomatic samples amplified PCR products measuring $1.2 \mathrm{kbp}$ indicating that the sample is infected with the phytoplasma. Sequence of $16 \mathrm{~S}$ rDNA gene of phytoplasma associated with the samples were known to be approximately $99 \%$ similar to those identified in Cuba which belong to the 16SrXII group (Stolbur group) (Gaur and Rao, 2008). In addition to being included in the 16SrXII group, phytoplasmas associated with sugarcane yellow leaf syndrome in India are also included in the 16SrI-B subgroup (Kumar et al., 2015). Similarly, the symptoms of yellow leaf syndrome in sugar cane plants in Egypt are associated with the phytoplasm of the 16SrI group (aster yellow phytoplasma) (ElSayed and Boulila, 2013).

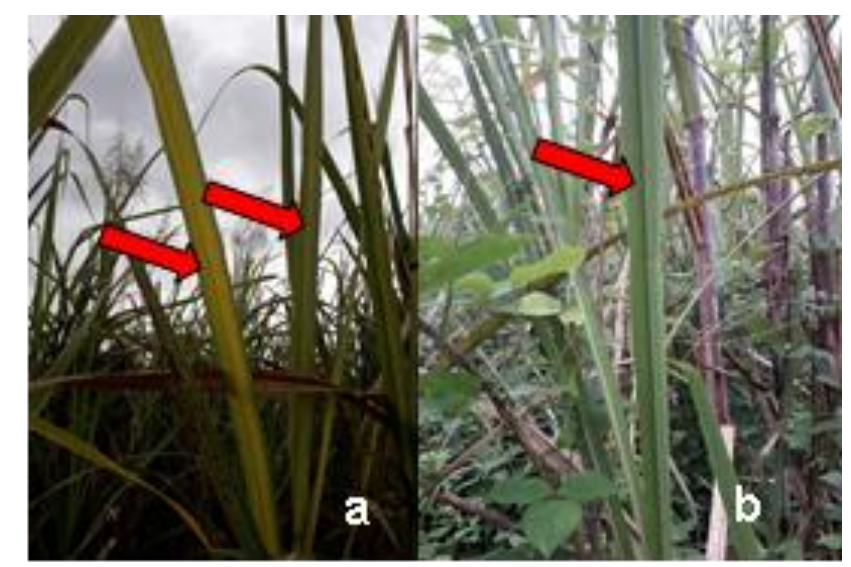

Fig. 1: Sugarcane plants are symptomatic with the yellowing midrib (arrows) (a) and are asymptomatic with green midrib (arrows) (b).

\section{Detection of phytoplasma in sugarcane plant using nested PCR}

The development of PCR technology has an important role in the study of phytoplasma detection. This is caused by the phytoplasma can not be grown on the culture medium so it is not possible to do detection as in bacteria that can be grown on culture medium. Therefore detection using PCR with a targeted gene of $16 \mathrm{~S}$ rDNA is currently the most commonly used method for detection of phytoplasma (Delic, 2012). In this study the researchers tried to detect the presence of phytoplasma in sugarcane plants that are symptomatic of yellow leaves or asymptomatic ones using nested PCR. Nested PCR is used to detect the phytoplasma of a normally low-titer sample (Delic, 2012). The first detection using the P1 and P7 primers did not show any amplified bands (Fig. 2), except on the grass sample.

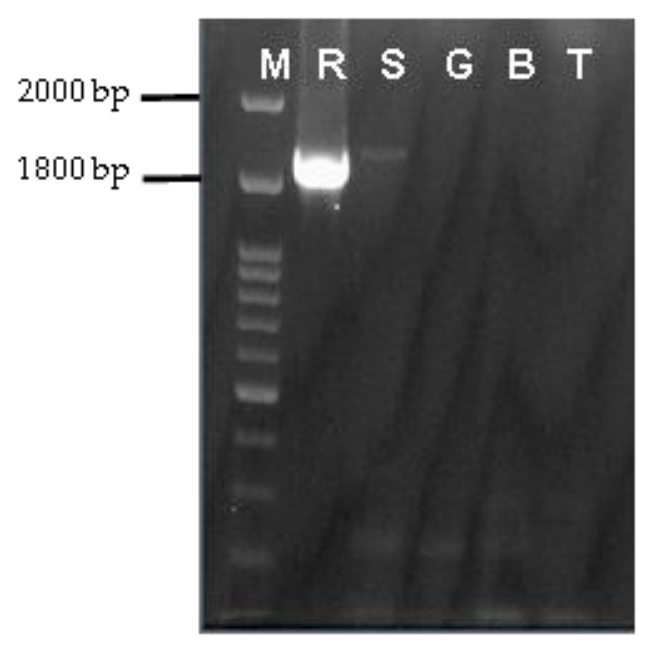

Fig. 2: Amplification of phytoplasmic DNA using primers P1/ P7 from grass samples (R), asymptomatic sugarcane (S), symptomatic sugarcane plants from Takalar (T), symptomatic sugarcane plants from Gowa (G) and symptomatic sugarcane plants from Bone District ( B). 100bp marker (M).

The second detection using the R16F2n and R16R2 primers showed that symptomatic leaf samples from Takalar and Bone districts also showed positive results with amplification of PCR products of approximately 1250 bp as well as in asymptomatic leaves (Fig. 3). Samples from Gowa 
District showed negative results with no amplification of PCR products (Fig. 3). This is allegedly because the yellowing symptoms that arise in the sugarcane sample from Gowa Regency are caused by other factors. The symptoms of yellowing leaves in sugar cane plants can be caused by viruses (Vega et al., 1997; Aljanabi, 2001). Symptoms caused by phytoplasma and virus are identical (Rutherford et al., 2004). According to Viswanathan et al. (2008) viral causes of yellowing leaves in India originated from the genus Polerovirus family Letuoviridae. There are 4 (four) virus genotypes identified namely BRA, CUB, PER and REU (Ahmad et al., 2006).

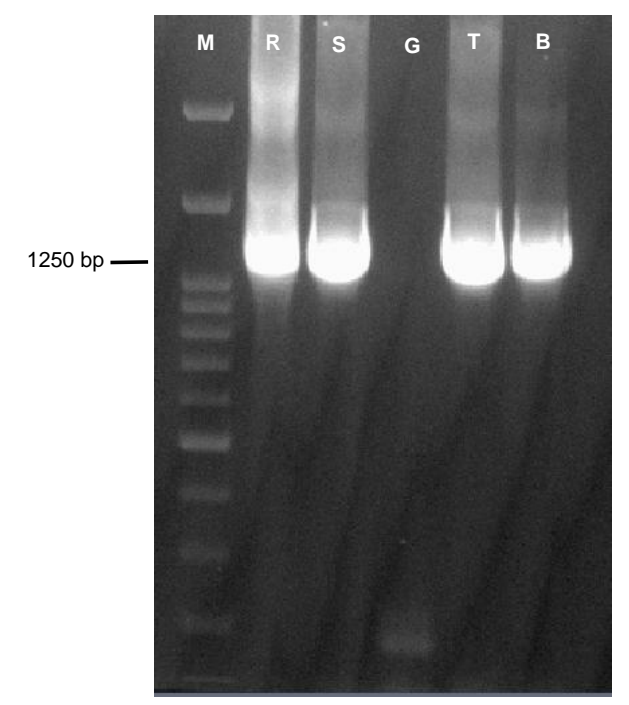

Fig. 3: Amplification of phytoplasmic DNA using R16F2n / R16R2 primers from grass (R) samples, asymptomatic sugarcane (S), symptomatic sugarcane plants from Takalar (T), symptomatic sugarcane plants from Gowa $(\mathrm{G})$ and symptomatic sugarcane plants from Bone District (B). 100bp marker (M).

Sugarcane samples were asymptomatic showing positive results after being detected using nested PCR. This shows that it can happen latent infection of phytoplasma in sugarcane plant. Soufi and Komor (2014) stated that it has happen latent infection of phytoplasma from the $16 \mathrm{SrI}$ and 16SrXI groups in asymptomatic sugarcane plants in Hawaii. Sequencing of DNA phytoplasma performed on the sample showing positive results after the nested PCR. The samples were samples derived from symptomatic sugarcane plantations from Takalar District, symptomatic sugarcane plants from Bone District and asymptomatic sugarcane plants. From the DNA sequencing results, a BLAST test of NCBI was performed with results showing that the phytoplasma in symptomatic sugarcane samples from Takalar Regency had 99\% homology with $\mathrm{Ca}$. Phytoplasma cynodontis, symptomatic sugarcane plant from Bone District $99 \%$ with $\mathrm{Ca}$. Phytoplasma cynodontis as well as samples of asymptomatic sugarcane plant $99 \%$ with Chrysanthemum morifolium little leaf and yellowing phytoplasma.

\section{Conclusion}

Phytoplasma was detected in sugarcane leaf samples originating from Takalar and Bone districts using nested PCR with amplification of PCR products of approximately $1250 \mathrm{bp}$, both symptomatic and asymptomatic samples. The symptoms of yellow leaves in Gowa Regency are thought to be caused by other factors. BLAST test results showed that the detectable phytoplasma has a 99\% homology value with Ca. Phytoplasma cynodontis and Chrysanthemum morifolium little leaf and yellowing phytoplasma.

\section{Conflict of interest statement}

Authors declare that they have no conflict of interest.

\section{Acknowledgement}

The authors wish to express gratitude to the Agricultural Human Resources Development Agency of the Ministry of Agriculture that has funded this research.

\section{References}

Ahmad, Y.A., Royer, M., Daugrois, J.H., Costet, L., Lett, J.M., Victoria, J.I., Girard, J.C., Rott, P., 2006. Geographical distribution of four sugarcane yellow leaf virus genotypes. Plant Dis. 90, 1156-1160. 
Aljanabi, S.M., Parmessur, Y., Moutia, Y., Saumtally, S., Dookun, A., 2001. Further evidence of the association of a Phytoplasma and a virus with yellow leaf syndrome in sugarcane. Plant Pathol. 50, 628-636.

Arocha, Y., Lopez, M., Fernandez, M., Pinol, B., Horta, D., Peralta, E. L., Almeida, R., Carvajal, O., Picornell, S., Wilson, M. R., Jones, P., 2005. Transmission of a sugarcane yellow leaf Phytoplasma by the Delphacid planthopper Saccharosydne saccharivora, a new vector of sugarcane yellow leaf syndrome. Plant Pathol. 54, 634-642.

CABI (CAB International), 2007. Crop Protection Compendium. (CD-Rom). Wallingford (UK): CABI. 2nd CD-Rom with the Guides in it.

Delic, D., 2012. Polymerase Chain Reaction for Phytoplasmas Detection. In: HernandezRodriguez P danGomez APR (Ed.). Polymerase Chain Reaction. pp91-118. In Tech.

Deng, S., Hiruki, C., 1991. Amplification of 16S rRNA genes from culturable and unculturable mollicutes. J. Microbiol. Meth. 14, 53-61.

Directorate General of Plantation, 2015. Plantation Statistics Indonesia Sugarcane Commodities 2014 - 2016. Jakarta.

ElSayed, A. I., Boulila, M., 2013. Molecular Identification and phylogenetic analysis of sugarcane yellow leaf Phytoplasma (SCYLP) in Egypt. J. Phytopathol. 162, 89-97.

Gaur, R. K., Rao, G. P., 2008. Detection of a 16SrXII Phytoplasma associated with sugarcane yellow leaf syndrome in India. Arch. Phytopath. Plant Prot. 43(11), 1132-1137.

Government of South Sulawesi Province, 2017. South Sulawesi Plantation Office Increase Production of Ten Leading Commodities. https://sulselprov.go.id/post/dinas-perkebunansulsel-tingkat-produce-sepuluh-komoditiunggulan. Retrieved on October 12, 2017.

Gundersen, D. E., Lee, I. M., 1996. Ultrasensitive detection of Phytoplasmas by nested PCR assays using two universal primer pairs. Phytopath. Mediter. 35, 144-151.

Kumar, S., Tiwari, A. K., Holkar, S. K., Duttamajumder, S. K., Rao, G. P., 2015. Characterization of a 16SrI-B sugroup Phytoplasma associated with sugarcane leaf yellows in India. Sugar Tech. 17(2), 156-161.

Rao, G. P., Mall, S., Marcone, C., 2012. Recent biotechnological approaches in diagnosis and management of sugarcane phytoplasma diseases. Func. Plant Sci. Biotechnol. 6(2), 19-29.

Rutherford, R. S., Brune, A. E., Nuss, K. J., 2004. Current status of research on sugarcane yellow leaf syndrome in Southern Africa. Proc. S. Afr. Sug. Technol. Assoc. 78, 173-180.

Soufi, Z., Komor, E., 2014. Latent infection of asymptomatic Hawaiian sugarcane cultivars with 16SrI dan 16SrXI Phytoplasmas. J. Gen. Plant Pathol. 80, 255-263.

Sugar Research Australia, 2013. Green Grassy Shoot Disease (GGSD). Information sheet.

Tiwari, A. K., Vishwakarma, S. K., Rao, G. P., 2012. Increasing incidence of sugarcane grassy shoot disease in Uttar Pradesh, India and its impact on yield and quality of sugarcane. Phytopathogenic Mollicutes. 2(2), 63-67.

Vega, J., Scagliusi, S. M. M., Ulian, E. C., 1997. Sugarcane yellow leaf disease in Brazil: Evidence of association with a luteovirus. Plant Dis. 81, 21-26.

Visvawathan, R., Balamularikrishan, M., Karuppaiah, R., 2008. Identification of three genotypes of sugarcane yellow leaf virus causing yellow leaf disease from India and their molecular characterization. Virus Genes. 37, 368-379.

Wongkaew, P., 2012. Sugarcane white leaf disease characterization, diagnosis development, and control strategies. Funct. Plant Sci. Biotechnol. 6(2), 73-84.

\section{How to cite this article:}

Utomo, C. Y. H., Baharuddin, Nur Amin, 2018. Phytoplasma detection on sugarcane crops in South Sulawesi. Int. J. Curr. Res. Biosci. Plant Biol. 5(8), 24-28.

doi: https://doi.org/10.20546/ijcrbp.2018.508.004 